\title{
APPLICATION OF BIOSTRATIGRAPHY TO THE RESOLUTION OF EXPLORATION AND RESERVOIR ARCHITECTURE PROBLEMS IN THE GULF OF MEXICO: PROSPECT "MARS"
}

O'NEILL, Brian J.; DUVERNAY, Alvin E.; RANNIK Matti; STYZEN, Michael J., Shell Offshore Inc., P.O. Box 61933, New Orleans, LA 70161, U.S.A

Biostratigraphy continues to play an important role in exploration and production drilling in the Gulf of Mexico Basin. Advances in logging and seismic technologies have not eliminated this need, but rather reinforced the importance of high-quality biostratigraphic correlation. At Shell Offshore Inc. exploration in deep water sediments has relied heavily on correlations using multiple fossil types (i.e. foraminifera, calcareous nannoplankton and palynomorphs). The signals from these three groups complement each other, and allow internal corroboration of the data increasing confidence in the interpretations even when based upon sparse faunas.

Exploratory drilling in the Mars Basin (Mississippi Canyon Area blocks 763, 806 and 807) was aided by the recognition of regional and sub-regional condensed sections between the turbidite basin-fill packages. These shales and marls were critical to correlation of individual reservoir units within the field and helped resolve complexities near vertical salt faces where seismic imaging is difficult. Nannofossil analysis documented a displaced block of late Miocene (Tortonian) sediments thrust over younger Miocene (Messinian) sediments by movement of the adjacent salt tablet.

Detailed biostratigraphic correlations were used to demonstrate stratigraphic pinch-out of reservoir sands rather than erosional or structural truncation near salt influencing volume estimates and the planning of well paths. Sediments equivalent to the entire deep reservoir section, Minylitha convalis to Discoaster bollii, were penetrated in the MC 806 \#1. Reservoir sands within this interval thinned from approximately 200 feet in the MC 807 \#1ST2 to less than 10 feet in the MC 806 \#1. This stratigraphic thinning occurred in a lateral distance of 5500 feet. 